\title{
Carcass characteristics of lambs fed diets with increasing levels of crude glycerin
}

\author{
Caio Alves da Costa ${ }^{1}$, Francisco Fernando Ramos de Carvalho ${ }^{2}$, Adriana Guim², \\ Gilcifran Prestes de Andrade ${ }^{2}$, Daniel Barros Cardoso ${ }^{2, *}$, Michel do Vale Maciel ${ }^{3}$, \\ Gabriela Gonçalves da Silva ${ }^{4}$, and Andreza Guedes de Oliveira Nascimento ${ }^{2}$
}

\begin{abstract}
* Corresponding Author: Daniel Barros Cardoso Tel: +55-81-3320-6555, Fax: +55-81-3320-6555 E-mail: danbarrc@hotmail.com
\end{abstract}

${ }^{1}$ Department of Animal Science, Federal University of Roraima, UFRR, Boa Vista, 69310-000, Roraima, Brazil

2 Department of Animal Science, Federal Rural University of Pernambuco, UFRPE, Recife, 52171 900, Pernambuco, Brazil

${ }^{3}$ Department of Animal Science, Federal University of Amazonas, UFAM, Parintins, 69152240 Amazonas, Brazil

${ }^{4}$ Department of Veterinary Medicine, Federal Rural University of Pernambuco, UFRPE, Recife, 52171900, Pernambuco, Brazil

\section{ORCID}

Caio Alves da Costa

https://orcid.org/0000-0003-0037-2595

Francisco Fernando Ramos de Carvalho

https://orcid.org/0000-0001-9211-0263 Adriana Guim

https://orcid.org/0000-0002-6589-9104

Gilcifran Prestes de Andrade

https://orcid.org/0000-0001-6347-7242

Daniel Barros Cardoso

https://orcid.org/0000-0002-6686-5766

Michel do Vale Maciel

https://orcid.org/0000-0002-6483-224X

Gabriela Gonçalves da Silva

https://orcid.org/0000-0001-9662-910X

Andreza Guedes de Oliveira Nascimento

https://orcid.org/0000-0002-5350-4750

Submitted Nov 3, 2018; Revised Dec 22, 2018 ; Accepted Jan 28, 2019
Objective: An experiment was conducted to evaluate the effects of increasing levels of crude glycerin $(0 \%, 6 \%, 12 \%$, and $18 \%)$ used as a substitute for corn in lamb feed on the quantitative characteristics of the carcass.

Methods: A total of 40 crossbred Santa Inês lambs that were four months old with a mean initial weight of $21.0 \pm 0.8 \mathrm{~kg}$ were randomly distributed in four treatments with ten replicates. The animals were slaughtered after 66 days of confinement. The effects of crude glycerin as a replacement for corn in the diet of the lambs on the carcass characteristics, commercial cut weight and yield and carcass measurements were studied.

Results: There was an increasing linear effect for body weight at slaughter with the replacement of corn by crude glycerin. The dry matter and metabolizable energy intakes, weight of the empty body, hot carcass weight and cold carcass weight showed a quadratic effect, with maximum crude glycerin levels estimated at $10.9 \%, 9.8 \%, 10.83 \%, 11.78 \%$, and $11.35 \%$, respectively. The initial $\mathrm{pH}$ was not influenced by the replacement of corn for crude glycerin, while the final $\mathrm{pH}$ presented a quadratic effect. The other parameters of the carcass and the weights and yields of commercial cuts were not influenced. There was also no effect of the diets on carcass morphometric measurements, except for the thoracic perimeter and the carcass compactness index, which presented quadratic and linear effects, respectively.

Conclusion: Crude glycerin can replace up to $18 \%$ of corn because it favours muscle tissue deposition without promoting changes in the main carcass characteristics of lambs.

Keywords: Glycerol; Energy; Performance; Sheep; Meat

\section{INTRODUCTION}

Among the various agro-industrial by-products currently used in ruminant feed, the most important are those derived from biodiesel production. Glycerin $\left(\mathrm{C}_{3} \mathrm{H}_{8} \mathrm{O}_{3}\right)$ is the main coproduct generated in the production of biodiesel and approximately $10 \%$ of the total volume of biodiesel produced corresponds to glycerin [1]. This co-product results from the formation of methyl esters of fatty acids from triglycerides [2].

Given that feed is the largest cost in livestock production, the use of alternative foods as co-products of biodiesel can be a viable alternative in economic and nutritional terms. Glycerin can be used as an energy ingredient in feed, replacing grains that are more expensive, to increase the profitability of the activity [3].

Glycerol is absorbed by the ruminal epithelium, metabolized in the liver and directed to gluconeogenesis by the action of the enzyme glycerol kinase, which converts it to glucose. Part of glycerol can be fermented to propionate in the rumen, which in turn is metabolized 
to oxaloacetate via the Krebs cycle in the liver and can be used to form glucose by the gluconeogenic route. Thus, crude glycerine (CG) has a potential application as a gluconeogenic substrate for ruminants [4]. In addition to serving as a source of energy, glycerol may also have positive effects on amino acid retention by inhibiting the activity of the enzymes phosphoenolpyruvate carboxykinase and glutamate dehydrogenase, which results in saving glucogenic amino acids, favouring the deposition of body protein [5].

Diet directly influences the consumption and digestibility of nutrients and consequently, the performance of animals, as well as body and carcass composition. The valuation of the carcass depends on the relationship between body weight and age at slaughter, among other factors. The goal is to obtain higher weights at younger ages to meet consumer market demands [6]. Some studies have evaluated the effects of CG on the diets of sheep and cattle by substituting concentrated feeds and/or associated with urea [7-9], and improvements were achieved or these changes did not impair weight gain and carcass characteristics.

Thus, the objective of this study was to evaluate the replacement of corn with CG in lamb feed on the quantitative and qualitative characteristics of the carcass.

\section{MATERIALS AND METHODS}

\section{Animal care}

The experiment was carried out at the Animal Evaluation Center with Small Ruminants III of the Animal Science Department of the Federal Rural University of Pernambuco (UFRPE), Recife - PE, Brazil. The experimental protocols were approved by the Institutional Animal Care and Use Committee of the Federal Rural University of Pernambuco (CEUAUFRPE) under license number 059/2016.

\section{Animals, experimental design and experimental diets}

We used 48 Santa Ines non-castrated male lambs that were four months old and had an average initial body weight of $21.0 \pm 0.8 \mathrm{~kg}$. Initially, lambs were identified, de-wormed with Ivermectin, immunized against clostridia and supplemented with an ADE vitamin compound. The animals were confined in individual pens with feeders and water suppliers. Initially, lambs were submitted to a period of 24 days to adapt to the experimental diets. After the adaptation period, the animals were randomly assigned one of four experimental treatments, which consisted of four concentrations of CG $(0 \%, 6 \%, 12 \%$, and $18 \%$ of dry matter $[\mathrm{DM}]$ ) as a substitute for ground corn, with ten replicates per treatment.

The ingredients used were tifton hay, ground corn, CG, soybean meal, urea, ammonium sulfate, mineral supply, limestone calcitic and dicalcium phosphate (Table 1). Crude glycerine was obtained from the production of biodiesel
Table 1. Chemical composition of ingredients on a dry matter basis $(\mathrm{g} / \mathrm{kg}$ of DM)

\begin{tabular}{lcccc}
\hline Item & $\begin{array}{c}\text { Crude } \\
\text { glycerin }\end{array}$ & $\begin{array}{c}\text { Soybean } \\
\text { meal }\end{array}$ & $\begin{array}{c}\text { Ground } \\
\text { corn }\end{array}$ & $\begin{array}{c}\text { Tifton } \\
\text { hay }\end{array}$ \\
\hline Dry matter (g/kg fresh weight) & 899 & 879 & 889 & 902 \\
Organic matter & 889.0 & 928.7 & 984.7 & 918.9 \\
Ash & 111 & 71.3 & 15.3 & 81.1 \\
Crude protein & 16.0 & 473 & 93.5 & 77.3 \\
Ether extract & 43.5 & 28.5 & 62.6 & 7.9 \\
NDFap & - & 165 & 160 & 735 \\
NFC & - & 237 & 686 & 122 \\
Glycerol & 805 & - & - & - \\
Sodium & 5.3 & - & - & - \\
Methanol & 38.2 & - & - & - \\
Density $\left(\mathrm{g} / \mathrm{cm}^{3}\right)$ & 0.97 & - & - & - \\
\hline
\end{tabular}

DM, dry matter; NDFap, neutral detergent fibre corrected for ash and protein; NFC, non-fibrous carbohydrates.

from cottonseed oil at the Bioenergy Unit of the Center for Strategic Technologies of the Northeast, Caetés (PE), Brazil. The diets were formulated with the aim of an average daily gain of $250 \mathrm{~g}$, according to the nutritional recommendations of the National Research Council [10] (Table 2).

Table 2. Proportion of ingredients and chemical composition of the experimental diets

\begin{tabular}{lcccc}
\hline \multirow{2}{*}{ Item } & \multicolumn{4}{c}{ Levels of crude glycerin (\%) } \\
\cline { 2 - 5 } & 0 & 6 & 12 & 18 \\
\hline Ingredients (g/kg) & & & & \\
$\quad$ Tifton hay & 40.00 & 40.00 & 40.00 & 40.00 \\
Ground corn & 40.35 & 34.10 & 27.85 & 21.60 \\
Soybean meal & 17.00 & 17.00 & 17.00 & 17.00 \\
Crude glycerin & 0.00 & 6.00 & 12.00 & 18.00 \\
Urea: AS & 0.50 & 0.75 & 1.00 & 1.25 \\
Mineral supply) & 1.50 & 1.50 & 1.50 & 1.50 \\
Limestone calcitic & 0.30 & 0.30 & 0.30 & 0.30 \\
Bicalcium phosphate & 0.35 & 0.35 & 0.35 & 0.35 \\
Chemical composition (g/kg DM) & & & & \\
Dry matter (g/kg fresh weight) & 890 & 891 & 894 & 892 \\
Organic matter & 921.5 & 915.7 & 910.0 & 904.3 \\
Crude protein & 161.6 & 163.3 & 164.9 & 166.6 \\
Ether extract & 33.3 & 32.0 & 30.4 & 29.2 \\
NDFap & 386.2 & 376.3 & 366.3 & 356.4 \\
Non-fiber carbohydrates & 348.5 & 356.2 & 364.5 & 372.2 \\
Total digestible nutrients ${ }^{4)}$ & 689 & 694 & 694 & 690 \\
\hline A & & &
\end{tabular}

AS, ammonium sulphate; DM, dry matter; NDFap, neutral detergent fiber corrected for ash and protein.

1) 9 parts of urea and 1 part of ammonium sulphate (AS)

${ }^{2)}$ Assurance levels provided by the manufacturer: Calcium, $150 \mathrm{~g}$; sulphur, $12 \mathrm{~g}$; phosphorus, $65 \mathrm{~g}$; magnesium-6.000 mg; sodium, 107 g; copper, 100 mg; cobalt, 175 mg; iron, 1,000 mg; fluorine, 650 mg; iodine, 175 mg; manganese, 1,440 mg; selenium, $27 \mathrm{mg}$; zinc, 6,000 mg.

${ }^{3)}$ Nine parts of urea and 1 part of ammonium sulfate (AS).

4) Estimated in the digestibility assay. 


\section{Experimental procedures and sampling}

The diets were provided as a complete mixture in individual feeders twice daily at 08:00 (50\%) and 16:00 (50\%), allowing $15 \%$ leftovers. Weekly samples were collected from the supplied diets (offer and refusal), and then the ingredients and leftovers were pre-dried in a forced ventilation oven at $55^{\circ} \mathrm{C}$ for 72 hours and ground in a Willey type mill with a $1 \mathrm{~mm}$ sieve. They were then submitted to further chemical analysis for their content of DM, organic matter, crude protein $(\mathrm{CP})$, and ethereal extract (EE) which was determined according to the AOAC [11] with methods numbers $967.03,942.05$, 981.10 , and 920.29 , respectively. Neutral detergent fibre (NDF) was determined according to Mertens [12], with corrections for protein and ash according to the methodologies described by Licitra et al [13] and Mertens [12], respectively. The concentrations of glycerol, methanol and sodium of the CG were determined by gas chromatography.

The total digestible nutrients (TDN) was estimated as suggested by Weiss [14], using TDN $=(\mathrm{CPd}+\mathrm{NFCd}+\mathrm{NDFapd}+$ [EEd $\times 2.25]$ ), where $\mathrm{CPd}$, digestible crude protein; NDFapd, digestible neutral detergent fibre corrected to protein and ash; NFCd, digestible non-fibrous carbohydrate; EEd, digestible ether extract). The digestible energy (DE) was estimated as $\mathrm{DE}(\mathrm{Mcal} / \mathrm{kg})=0.04409 \times \mathrm{TDN}(\%)$. The conversion of DE to metabolizable energy (ME) was estimated as $\mathrm{DE} \times 0.82$. The DM intake, ME intake, feed conversion (FC) and feed efficiency used in the results and discussion of the present study were obtained by Andrade et al [15].

After 66 days of feeding, the lambs were fasted for 16 hours, weighed to obtain body weight at slaughter (BWS) and then slaughtered by cerebral concussion followed by jugular and carotid venesection. Pre-harvest handling was in accordance with good animal welfare practices and our slaughtering procedures followed the Sanitary and Industrial Inspection Regulation for Animal Origin Products [16].

After obtaining BWS, bleeding, evisceration and head and limb removal were performed, and the carcass was weighed to obtain the hot carcass weight (HCW). The gastrointestinal tract was also weighed when it was full and then when it was empty, and it was weighed again to obtain the weight of the contents of the gastrointestinal tract and to calculate the empty body weight (EBW). The yields of the hot (HCY) and biological (BY) carcass were determined using the formulas HCY $(\%)=(\mathrm{HCW} / \mathrm{BWS}) \times 100$ and BY $(\%)=(\mathrm{HCW} / \mathrm{EBW}) \times 100$.

Subsequently, the carcasses were taken to the cold room with an average temperature of $4^{\circ} \mathrm{C}$ where they remained for 24 hours, and after this cooling period they were weighed to obtain the cold carcass weight (CCW). Cold carcass yield (CCY) and cooling losses (CL) were determined according to the equations CCY $(\%)=(\mathrm{CCW} / \mathrm{BWS}) \times 100$ and $\mathrm{CL}(\%)$ $=(\mathrm{HCW}-\mathrm{CCW} / \mathrm{HCW}) \times 100$.

After the cooling period, morphometric measurements were performed on the carcasses. The carcass compactness index (CCI) and the leg compactness index (LCI) were also calculated using the following equations: $\mathrm{CCI}(\mathrm{kg} / \mathrm{cm})=\mathrm{CCW} /$ internal length carcass; and LCI $(\mathrm{cm} / \mathrm{cm})=$ hind width/leg length [17]. After which each carcass was divided sagittally. The left halves of the carcasses were sectioned in six anatomical regions that constitute meat cuts according to the methodology adapted from Cezar and Souza [17]: neck, shoulder, rib, saw, loin, and leg.

To obtain the longissimus muscle area in the left halves of the carcasses, a cut was performed between the 12th and 13th ribs to expose the longissimus dorsi muscle. This area was hatched on a transparent plastic sheet and was measured later using a digital planimeter (HAFF, Digiplan model; Pfronten, Baviera, Germany). In the same muscle, we measured subcutaneous fat thickness using callipers. The carcass $\mathrm{pH}$ was measured at 45 minutes and 24 hours post mortem in the semimembranosus muscle using a portable $\mathrm{pH}$ meter (Testo, model 205; Testo Instrument Co. LTD., Berlin, Germany).

\section{Statistical analysis}

The experimental design was a randomized block with four treatments and ten replicates. The initial weight of the animals was the criterion for the formation of blocks according to the model:

$$
Y_{i j}=\mu+T_{i}+b_{j}+e_{i j}
$$

where $Y_{i j}=$ observed value of the dependent variable; $\mu=$ general mean; $T_{i}=$ treatment effect ( $\mathrm{i}=1$ to 4$) ; b_{j}=$ effect of block $j(\mathrm{j}=1$ to 4$)$ and $e_{i j}=$ experimental error. The variables studied were interpreted by analysis of variance and regression analysis, considering the level of 5\% probability for the type I error, using general linear model and REG procedures for $\mathrm{L}$ linear and Q quadratic effect of the SAS software package [18].

\section{RESULTS}

\section{Carcass characteristics}

There was an increasing linear effect $(\mathrm{p}<0.05)$ on BWS with replacement of corn by CG (Table 3). The DM intake, ME intake (Mcal/kg of DM), EBW, HCW, and CCW presented a quadratic effect $(\mathrm{p}<0.05)$ (Table 3$)$, with maximum values of $1,293.76 \mathrm{~g} / \mathrm{d}, 3.27,31.33,18,10$, and $17.15 \mathrm{~kg}$, estimated at CG levels of $10.9 \%, 9.8 \%, 10.83 \%, 11.78 \%$, and $11.35 \%$, respectively. The FC presented a quadratic effect $(\mathrm{p}<0.05)$, with an estimated 4.7 minimum conversion for the $10.5 \%$ level of replacement, while the feed efficiency was not influenced by treatments (Table 3).

There was no influence ( $p>0.05)$ of the corn replacement levels by CG on hot and cold carcass yields, BY, or CL \% (Table 
Table 3. Productive parameters and carcass characteristics of lambs fed with crude glycerin in replacement for corn

\begin{tabular}{|c|c|c|c|c|c|c|c|}
\hline \multirow{2}{*}{ Item } & \multicolumn{4}{|c|}{ Levels of crude glycerin (\% DM) } & \multirow{2}{*}{ SEM } & \multicolumn{2}{|c|}{$\mathrm{p}$-value } \\
\hline & 0 & 6 & 12 & 18 & & L & Q \\
\hline \multicolumn{8}{|l|}{ Productive parameters } \\
\hline Dry matter $(g / d) *$ & $1,251.3$ & $1,286.9$ & $1,303.2$ & $1,272.9$ & 20.94 & 0.152 & $0.043^{11}$ \\
\hline Metabolizable energy (Mcal/kg)* & 3.12 & 3.23 & 3.27 & 3.17 & 10.67 & 0.426 & $0.034^{2)}$ \\
\hline Feed conversion* & 5.5 & 5.0 & 4.8 & 5.1 & 0.073 & 0.345 & $0.041^{3)}$ \\
\hline Feed efficiency* & 17.5 & 19.7 & 20.5 & 19.3 & 0.489 & 0.136 & 0.086 \\
\hline \multicolumn{8}{|l|}{ Carcass characteristics } \\
\hline Body weight at slaughter $(\mathrm{kg})$ & 32.97 & 35.44 & 36.65 & 35.77 & 0.453 & $0.014^{4)}$ & 0.053 \\
\hline Empty body (kg) & 28.62 & 30.45 & 31.62 & 30.00 & 0.355 & 0.080 & $0.012^{5)}$ \\
\hline Hot carcass weight $(\mathrm{kg})$ & 16.02 & 17.83 & 17.89 & 17.61 & 0.213 & 0.004 & $0.004^{6}$ \\
\hline Cold carcass weight $(\mathrm{kg})$ & 15.43 & 16.94 & 17.04 & 16.72 & 0.203 & 0.022 & $0.018^{7)}$ \\
\hline Cooling losses (\%) & 5.08 & 4.96 & 5.25 & 5.06 & 0.119 & 0.324 & 0.284 \\
\hline Hot carcass yield (\%) & 50.56 & 50.45 & 49.14 & 49.28 & 0.440 & 0.209 & 0.896 \\
\hline Cold carcass yield (\%) & 46.84 & 47.93 & 46.57 & 46.78 & 0.373 & 0.659 & 0.565 \\
\hline Biological yield (\%) & 58.17 & 58.61 & 56.93 & 58.77 & 0.440 & 0.977 & 0.453 \\
\hline Longissimus muscle area $\left(\mathrm{cm}^{2}\right)$ & 11.47 & 11.51 & 11.94 & 11.08 & 0.298 & 0.791 & 0.471 \\
\hline Fat thickness $(\mathrm{mm})$ & 0.90 & 0.96 & 0.97 & 0.90 & 0.038 & 0.450 & 0.235 \\
\hline pH inicial & 6.54 & 6.51 & 6.57 & 6.50 & 0030 & 0.786 & 0.723 \\
\hline pH ultimate & 5.43 & 5.34 & 5.32 & 5.42 & 0.021 & 0.806 & $0.031^{8)}$ \\
\hline
\end{tabular}

DM, dry matter; SEM, standard error of the mean; $L$, linear effect; $Q$, quadratic effect.

1) $\hat{Y}=1258.21+6.499 X-0.297 X^{2}{ }^{2)} \hat{Y}=3.11+0.0294 X-0.0015 X^{2}$.

${ }^{3)} \hat{Y}=5.24-0.089 X+0.0048 X^{2}{ }^{4)} \hat{Y}=32.93+0.579 X$

${ }^{5)} \hat{Y}=28.52+0.520 X-0.024 X^{2}{ }^{6}{ }^{6} \hat{Y}=16.09+0.3417 X-0.0145 X^{2}$.

${ }^{7)} \hat{Y}=15.48+0.295 X-0013 X^{2} .{ }^{8)} \hat{Y}=5.43-0.024 X+0001 X^{2}$.

*Andrade et al [15].

3). There was no effect ( $\mathrm{p}>0.05)$ of the diets on the longissimus muscle area or subcutaneous fat thickness (Table 3). The initial $\mathrm{pH}$ (45 min) after slaughter was not influenced ( $\mathrm{p}>0.05)$, but the final $\mathrm{pH}(24 \mathrm{~h})$ presented quadratic behaviour $(\mathrm{p}<$ 0.05 ), with a minimum value of 5.28 that was estimated at the CG level of $12 \%$ (Table 3).

\section{Weights and yields of commercial cuts}

The weight and yields of the meat cuts (neck, shoulder, ribs, saw, loin, and leg) were not influenced ( $p>0.05$ ) by replacement (Table 4).

\section{Morphometric measurements}

There was a quadratic effect $(\mathrm{p}<0.05)$ on the thoracic perim-

Table 4. Weight and yield of commercial cuts of lambs fed with crude glycerin in replacement for corn

\begin{tabular}{|c|c|c|c|c|c|c|c|}
\hline \multirow{2}{*}{ Item } & \multicolumn{4}{|c|}{ Levels of crude glycerin (\% DM) } & \multirow{2}{*}{ SEM } & \multicolumn{2}{|c|}{ p-value } \\
\hline & 0 & 6 & 12 & 18 & & $\mathbf{L}$ & Q \\
\hline \multicolumn{8}{|l|}{ Weight (kg) } \\
\hline Neck & 0.72 & 0.80 & 0.82 & 0.78 & 0.028 & 0.443 & 0.340 \\
\hline Shoulder & 1.34 & 1.49 & 1.34 & 1.35 & 0.025 & 0.636 & 0.158 \\
\hline Ribs & 1.48 & 1.55 & 1.62 & 1.56 & 0.029 & 0.216 & 0.274 \\
\hline Saw & 0.75 & 0.93 & 0.90 & 0.87 & 0.032 & 0.251 & 0.110 \\
\hline Loin & 0.72 & 0.81 & 0.78 & 0.79 & 0.018 & 0.221 & 0.273 \\
\hline Leg & 2.54 & 2.75 & 2.57 & 2.70 & 0.046 & 0.487 & 0.645 \\
\hline \multicolumn{8}{|l|}{ Yield (\%) } \\
\hline Neck & 9.59 & 9.53 & 10.20 & 9.73 & 0.318 & 0.723 & 0.760 \\
\hline Shoulder & 17.77 & 17.92 & 16.73 & 16.79 & 0.262 & 0.085 & 0.928 \\
\hline Ribs & 19.64 & 18.59 & 20.18 & 19.37 & 0.282 & 0.766 & 0.833 \\
\hline Saw & 9.90 & 10.93 & 11.24 & 10.77 & 0.286 & 0.269 & 0.204 \\
\hline Loin & 9.49 & 9.76 & 9.74 & 9.85 & 0.190 & 0.547 & 0.843 \\
\hline Leg & 33.60 & 33.26 & 31.91 & 33.49 & 0.392 & 0.640 & 0.223 \\
\hline
\end{tabular}

DM, dry matter; SEM, standard error of the mean; L, linear effect; Q, quadratic effect. 
eter, with a maximum length of $71.63 \mathrm{~cm}$, estimated at the CG level of $12.20 \%$ (Table 5). The other morphometric measurements were not influenced ( $>>0.05)$ (Table 5). The LCI was not influenced ( $p>0.05)$ by the replacement of corn with CG, but an increasing linear effect $(\mathrm{p}<0.05)$ was found for the CCI (Table 5).

\section{DISCUSSION}

The observed behaviour for the EBW, HCW, and CCW variables may be related to DM intake and ME intake due the fact that glycerol from CG may have increased dietary energy efficiency by the microorganisms in the rumen and consequently favoured the synthesis of tissues in the body of the animal. The BWS values are between the intervals of studies on sheep of the same age that were fed CG in confinement and were slaughtered when they were between 25 and $38 \mathrm{~kg}[7,8,19,20]$. In the present study the animals were slaughtered at an average of $35.21 \mathrm{~kg}$ and presented a linear behaviour that increased with the inclusion of CG in the diets, with a better performance of the animals as the amount of corn replaced by CG increased.

The values found for the CL \% of the carcasses were within the range cited by Martins et al [21] which is between $1 \%$ and 7\%. Lage et al [19] reported lower HCY (44.32\%) and CCY (42.92\%) values when they evaluated the effects of CG $(36.2 \%$ glycerol). However, their CG inclusions were lower, mainly the glycerol content present in glicerin, reflecting the metabolism and utilization of glycerol by the animals. In addition, the carcass yield is directly affected by carcass weight. The performance presented (Table 3) by the animals in confinement was reflected in the HCW, which presented satisfactory values and influenced the significant performance in carcass yield.

The longissimus muscle area that we obtained can be con- sidered satisfactory. Lage et al [19] evaluated the effects of inclusion of CG with $36.2 \%$ of glycerol in the diet of confined sheep slaughtered at a mean of $32.72 \mathrm{~kg}$ and found an average of $12.1 \mathrm{~cm}^{2}$, while Rego et al [8] and Carvalho et al [20] obtained much higher values of 13.66 and $14.44 \mathrm{~cm}^{2}$. According to Cezar and Souza [17] the determination of the longissimus muscle area measured as the longissimus dorsi muscle has traditionally been used as a good estimate of carcass musculature and is directly correlated with the muscle/bone relationship in the most important cuts of the carcass, which exerts an important influence on the classification of the carcass and the evaluation of the final price of the meat.

The absence of an influence of the diets on subcutaneous fat thickness could be related to the time of confinement, which was of 90 days for animals that were four months old. Consequently, slaughter occurred before the adipose tissue began its major deposition because according to Gerrard and Grant [22] adipose tissue develops last, after peak muscle growth. According to Osório et al [23] subcutaneous fat thickness is associated with several factors, including race, gender, diet, the duration of the feeding period and confinement. Therefore, it was not related to the energetic level of the diets, but to the chronology of body development, meaning the animals did not reach their maximum body development.

The behaviour observed for the final $\mathrm{pH}(24 \mathrm{~h})$ may have occurred as a result of the increased ME intake with increasing CG levels. A hypothesis for this behaviour would be that the increase in muscle glycogen reserves, which were converted to lactic acid later, thereby reduced the final shell $\mathrm{pH}$. Silva Sobrinho et al [24] found that the final $\mathrm{pH}$ value of sheep meat can range from 5.5 to 5.8. Therefore, the $\mathrm{pH}$ that we found at 24 hours was close to this range, indicating no preslaughter stress.

Regarding the commercial cuts, the leg was the cut of greater weight and, consequently, higher yield (Table 4). Ac-

Table 5. Morphometric measurements of carcass $(\mathrm{cm})$ of lambs fed with crude glycerin in replacement for corn

\begin{tabular}{|c|c|c|c|c|c|c|c|}
\hline \multirow{2}{*}{ Item } & \multicolumn{4}{|c|}{ Levels of crude glycerin (\% DM) } & \multirow{2}{*}{ SEM } & \multicolumn{2}{|c|}{ p-value } \\
\hline & 0 & 6 & 12 & 18 & & $\mathbf{L}$ & Q \\
\hline External carcass length & 56.90 & 57.60 & 57.70 & 57.65 & 0.367 & 0.496 & 0.627 \\
\hline Internal carcass length & 63.10 & 64.30 & 64.60 & 63.35 & 0.379 & 0.762 & 0.120 \\
\hline Thoracic width & 21.45 & 22.10 & 22.50 & 22.50 & 0.226 & 0.089 & 0.479 \\
\hline Thoracic perimeter & 67.45 & 70.70 & 71.50 & 70.75 & 0.159 & 0.001 & $0.022^{1}$ \\
\hline Thoracic depth & 24.95 & 25.20 & 25.40 & 25.20 & 0.467 & 0.524 & 0.500 \\
\hline Hind width & 22.75 & 22.73 & 22.35 & 22.80 & 0.168 & 0.883 & 0.504 \\
\hline Hind perimeter & 62.65 & 64.90 & 64.30 & 64.65 & 0.378 & 0.112 & 0.208 \\
\hline Leg length & 41.65 & 40.90 & 42.30 & 42.20 & 0.190 & 0.062 & 0.364 \\
\hline Leg perimeter & 39.70 & 39.95 & 38.70 & 39.40 & 0.297 & 0.433 & 0.712 \\
\hline $\mathrm{CCl}(\mathrm{kg} / \mathrm{cm})$ & 0.24 & 0.26 & 0.26 & 0.26 & 0.003 & $0.010^{2)}$ & 0.060 \\
\hline $\mathrm{LCl}(\mathrm{cm} / \mathrm{cm})$ & 0.55 & 0.56 & 0.53 & 0.54 & 0.005 & 0.279 & 0.880 \\
\hline
\end{tabular}

DM, dry matter; SEM, standard error of the mean; L, linear effect; Q, quadratic effect; $\mathrm{CCl}$, carcass compactness index; $\mathrm{LCl}$, leg compactness index.

1) $\hat{Y}=67.49+0.6783-0.0278 X^{2}{ }^{2)} \hat{Y}=0.24+0.003 X$. 
cording to Silva Sobrinho [25] this becomes important because it is a region with greater muscularity and a greater yield of the edible part. In addition to the leg, the shoulder and the loin are the most valued commercial cuts of the carcass. Thus, when greater yields of these cuts are obtained, the carcass has a higher value. In this research, the three cuts in question comprised $60.08 \%$ of the yield. These results correspond to those reported by Furusho-Garcia et al [26] where the shoulder and leg represented more than $50 \%$ of the carcass, and these cuts are the best predictors of the total contents of the carcass tissues.

Body development occurs in the following sequence: bones, muscle and fat. The bone structure is almost fully developed, in dimension, in the first months of life of the animal, followed by muscle hypertrophy and finally the deposition of adipose tissue [22]. The morphometric results observed in this study demonstrate that the linear and circular measurements of the carcass did not vary statistically between the inclusion levels of CG in the diet.

The increasing linear effect observed on the CCI is related to the CCW, which also increased linearly with replacement. The values found are within the range of the indexes for sheep that are documented in the literature, indicating good deposition of muscle tissue per unit length. The higher the CCI, the greater the deposition of muscle tissue per unit area and the better the carcass will be evaluated. Thus, the replacement of corn by CG favours the deposition of muscle tissue.

\section{CONCLUSION}

Crude glycerin can replace up to $18 \%$ of corn and favour the muscle tissue deposition. Therefore, it presents itself as an excellent alternative food, contributes to obtaining more valued carcasses and consequently, corresponds to the final value of commercialized meat.

\section{CONFLICT OF INTEREST}

We certify that there is no conflict of interest with any financial organization regarding the material discussed in the manuscript.

\section{ACKNOWLEDGMENTS}

The authors are grateful for the support and funding from the National Council for Scientific and Technological Development $(\mathrm{CNPq})$ and the Commission for the Improvement of Higher Education Personnel (CAPES).

\section{REFERENCES}

1. Dasari MA, Kiatsimkul PP, Sutterlin WR, Suppes GJ. Low- pressure hydrogenolysis of glycerol to propylene glycol. Appl Catal A 2005;281:225-31. https://doi.org/10.1016/j.apcata. 2004.11.033

2. Chanjula P, Pakdeechanuan P, Wattanasit S. Effects of feeding crude glycerin on feedlot performance and carcass characteristics in finishing goats. Small Rumin Res 2015;123:95102. https://doi.org/10.1016/j.smallrumres.2014.11.011

3. Chanjula P, Raungprim T, Yimmongko S, Poonko S, Majarune S, Maitreejet W. Effects of elevated crude glycerin concentrations on feedlot performance and carcass characteristics in finishing steers. Asian-Australas J Anim Sci 2016;29:80-8. https://doi.org/10.5713/ajas.15.0219

4. Krehbiel CR. Ruminal and physiological metabolism of glycerin. J Anim Sci 2008;86:392.

5. Cerrate S, Yan F, Wang C, Coto C, Sacakli P, Waldroup PW. Evaluation of glycerine from biodiesel production as a feed ingredient for broilers. Int Poult Sci 2006;5:1001-7. http:// dx.doi.org/10.3923/ijps.2006.1001.1007

6. Pereira ES, Pimentel PG, Fontenele RM, Medeiros AN, Regadas Filho JGL, Villarroel ABS. Characteristics and yields of carcass and cuts in Santa Ines sheep fed with different concentrations of metabolizable energy. Acta Sci 2010;32:431-7.

7. Barros MCC, Marques JAM, Silva FF, et al. Crude glycerin in diets for wethers in feedlot: intake, digestibility, performance, carcass and meat traits. Semin Ciênc Agrár 2015;36: 453-66. http://dx.doi.org/10.5433/1679-0359.2015v36n1p453

8. Rego FCA, Françozo MC, Ludovico A, et al. Development, economic viability and attributes of lamb carcass from confined animals fed on different amounts of crude glycerin. Semin Ciênc Agrár 2015;36:3445-54. http://dx.doi.org/10.5433/16790359.2015v36n5p3445

9. D'Aurea AP, Ezequiel JMB, D'Aurea EMO, et al. Glycerin associated with urea in finishing beef cattle: performance and meat characteristics. Arq Bras Med Vet Zootec 2017;69: 165-72. http://dx.doi.org/10.1590/1678-4162-8895

10. National Research Council (NRC). Nutrient requirements of small ruminants: sheep, goats, cervids, and new world camelids. Washington, DC, USA: National Academy Press; 2007.

11.AOAC. Official methods of analysis, 17th ed. Association of Analytical Chemists. Gaithersburg: VA, USA: AOAC International; 2000.

12.Mertens DR. Gravimetric determination of amylase-treated neutral detergent fibre in feeds with refluxing beakers or crucibles: a collaborative study. J AOAC Int 2002;85:1217-40.

13. Licitra G, Hernandez TM, Van Soest PJ. Standardization of procedures for nitrogen fractionation of ruminant feeds. Anim Feed Sci Technol 1996;57:347-58. https://doi.org/10.1016/03778401(95)00837-3

14. Weiss WP. Energy prediction equations for ruminant feeds. In: Cornell Nutrition Conference Feed Manufactures, 61th Proceedings; Ithaka, NY, USA: Cornell University; 1999. pp. 176-85. 
15. Andrade GP, Carvalho FFR, Batista ÂMV, et al. Evaluation of crude glycerin as a partial substitute of corn grain in growing diets for lambs. Small Rumin Res 2018;165:41-7. https://doi. org/10.1016/j.smallrumres.2018.06.002

16. BRASIL, Ministry of Agriculture, Livestock and Food Supply. Normative Instruction Nunber 3 of January 17th, 2000 [Internet]. Technical regulation on methods of desensitization for humanitarian slaughtering of animals. Official Journal of the Union, Brasília, January 24th, 2000, section 1. p.

17.Cezar MF, Souza WH. Sheep and goat carcasses: obtaining, evaluation and classification. Uberaba, MG, Brazil: Tropical Agriculture Publishing; 2007. 147 p.

18.SAS. Statistical analysis system. User's guide, version 9.0. Cary, NC, USA: SAS Institute Inc.; 2002.

19. Lage JF, Paulino PVR, Pereira LGR, et al. Carcass characteristics of feedlot lambs fed crude glycerin contaminated with high concentrations of crude fat. Meat Sci 2014;96:108-13. https:// doi.org/10.1016/j.meatsci.2013.06.020

20. Carvalho VB, Leite RF, Almeida MTC, et al. Carcass characteristics and meat quality of lambs fed high concentrations of crude glycerin in low-starch diets. Meat Sci 2015;110:28592. https://doi.org/10.1016/j.meatsci.2015.08.001

21.Martins RRC, Oliveira NM, Osorio JCS, Osório MTM. Live weight at slaughter as an indicator of carcass weight and quantitative and qualitative characteristics in Ideal sheep. Bagé, Brazil: Embrapa Pecuária Sul. (Research Bulletin, 21); 2000. $29 \mathrm{p}$.

22. Gerrard DE, Grant AL. Principles of animal growth and development. Revised Printing. Purdue University, Dubuque, Iowa, USA: Kendall/Hunt Publishing Company; 2006. 264 p.

23. Osório JCS, Osório MTM, Oliveira NRM, Siewerdt L. Carcass quality, morphology and evaluation. Pelotas, Brazil: University Press and Graphics - UFPel, 2002. 195 p.

24. Silva Sobrinho AG, Purchas RW, Kadim IT, Yamamoto SM. Meat quality in lambs of different genotypes and ages at slaughter R Bras Zootec 2005;34:1070-8. https://dx.doi.org/10.1590/ S1516-35982005000300040

25.Silva Sobrinho AG. Sheep breeding. 2 th ed. Jaboticabal, São Paulo, Brazil: FUNEP (Research Support Foundation); 2001. $302 \mathrm{p}$.

26. Furusho-Garcia IFF, Perez JRO, Bonagurio S, Lima AL, Quintão FA. Study of the carcass cuts of Santa Inês and crosses with Texel, ile de France and Bergamacia lambs. R Bras Zootec 2004;33:453-62. http://dx.doi.org/10.1590/S1516-35982004 000200024 